\title{
NARDIA HIROSHII AMAKAWA - A NEW SPECIES FOR NORTH AMERICAN LIVERWORT FLORA AND THE KEY TO NARDIA SPECIES IN NORTH PACIFIC
}

\section{NARDIA HIROSHII AMAKAWA - НОВЫЙ ВИД ДЛЯ ФЛОРЫ ПЕЧЕНОЧНИКОВ СЕВЕРНОЙ АМЕРИКИ И КЛЮЧ ДЛЯ ОПРЕДЕЛЕНИЯ NARDIA В СЕВЕРНОЙ ПАЦИФИКЕ}

\author{
VADIM A. BAKALIN ${ }^{1,2}$ \\ ВАДИМ А. БАКАЛИН ${ }^{1,2}$
}

Abstract

Nardia hiroshii Amakawa is newly recorded for North America. The species is closely related to N. unispiralis Amakawa, but differs from the latter in bispiral elaters, larger and regular underleaves and rhizoids distribution. $N$. hiroshii is described and illustrated basing on the North American material. The key with notes on distribution is provided for all Nardia taxa recognized around North Pacific.

Резюме

Nardia hiroshii Amakawa выявлена впервые в Северной Америке. Морфологически вид близок к N. unispiralis Amakawa, от которой отличается двуспиральными элатерами, более крупными и регулярными амфигастриями и ризоидами, сосредоточенными преимущественно у основания амфигастриев. По североамериканскому материалу приводится описание и иллюстрации $N$. hiroshii. Составлен ключ для определения видов рода Nardia, распространенных в Северной Пацифике.

KEYWORDS: Eastern Asia, Hepaticae, Jungermanniaceae, Nardia, North Pacific

\section{INTRODUCTION}

In the course of the revision of some genera for North American flora, I paid attention to the a specimen collected in California, which contained plants of lophozioid appearance, but undoubtedly belonged neither to Lophozia nor Leiocolea. The plants were identified as Nardia hiroshii Amakawa, the taxon known before from Japan and the adjacent Kuril Islands (Amakawa, 1959; Bakalin et al., 2009), so it was difficult to expect its occurrence in North America. Since it is more or less troublesome to recognize this species as Nardia (which explains why the specimen had been identified as Lophozia collaris (Nees) Dumort., MO 3966877) and because of long misinterpretation of this taxon, I present a short account on this record and supply it with the general key to the Nardia distributed around northern Pacific.

Nardia hiroshii was described from Honshu (Amakawa, 1959) as species similar in appearance to N. japoni$c a$ Steph., but differing in smaller underleaves and oilbody structure (granulate versus homogenous). Sporophytes were unknown for this species until 2007 (Bakalin et al., 2009). Shortly after description $N$. hiroshii was synonymized by Váňa (1976) with N. unispiralis Amaka- wa suggested then as a Japanese endemic. My experience on the two taxa relies on the study of the South Kuril Islands flora where both taxa occur and probably are more widespread than in Japan. I should agree with Ván̆a (1976) that both taxa are closely related to each other and are rather distant from $N$. japonica, but I suppose that they are separate species (Bakalin et al., 2009). The main distinctions are: 1) $N$. hiroshii has bispiral elaters versus typically unispiral in N. unispiralis; 2) underleaves in $N$. hiroshii are always regular, although sometimes (rare forms) small and hardly visible, versus commonly disappearing and vestigial in N. unispiralis; 3) underleaves in $N$. hiroshii are $280 \mu \mathrm{m}$ long, versus somewhat smaller, up to $160 \mu \mathrm{m}$, in N. unispiralis [Amakawa (1959) states in the description of $N$. unispiralis: "underleaves small, subulate, $0.16 \mathrm{~mm}$ long, $0.55 \mathrm{~mm}$ wide" (1.c.: 287); I suggest that the second numeral should be printed as " $0.055 \mathrm{~mm}$ "]; 4) rhizoids are restricted mostly to underleaf bases in $N$. hiroshii, versus rhizoids continuously distributed along ventral side of stem in $N$. unispiralis.

Both N. hiroshii and N. unispiralis form a peculiar group of Nardia with "lophozioid" appearance. This pair

\footnotetext{
1 - Botanical Garden-Institute FEB RAS, Makovskogo Street, 142, Vladivostok, 690024, Russia - Россия, 690024, Владивосток, ул. Маковского, 142, Ботанический сад-институт ДВО РАН

2 - Institute of Biology and Soil Science FEB RAS, Stoletiya Vladivostoka Avenue, 159, Vladivostok, 690022, Russia - Россия, 690022, Владивосток, пр. Столетия Владивостока, 159, Биолого-почвенный институт ДВО РАН; e-mail: v_bak@list.ru
} 


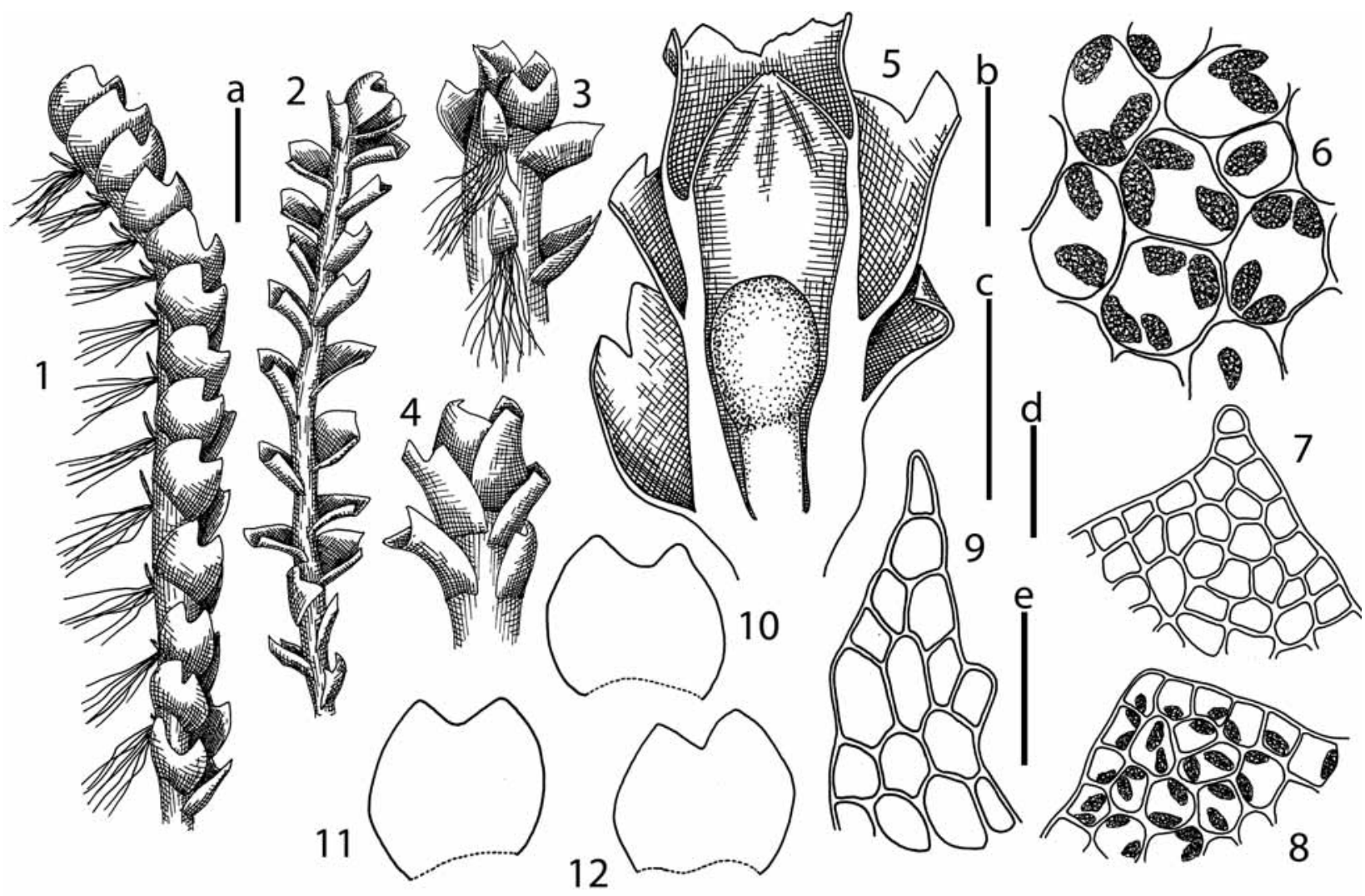

Fig. 1. Nardia hiroshii Amakawa. 1 - shoot, lateral view; 2 - shoot, dorsal view; 3 - perianthous plant apex, ventral view; 4 - perianthous plant apex, dorsal view; 5 - perianth longitudinal section, 6 - midleaf cells with oil-bodies; 7 - lobe apex; 8 lobe apex, showing oil-bodies; 9 - underleaf; 10-12 - leaves. Scales: a - $1 \mathrm{~mm}$, for 1-4, 10-12; b - 500 $\mu \mathrm{m}$, for 5; $\mathrm{c}-50 \mu \mathrm{m}$, for 6; $\mathrm{d}-100 \mu \mathrm{m}$, for 7, 8; e $-100 \mu \mathrm{m}$, for 9. Drawn from USA, California, A.T. Whittemore 4157 (MO3966877).

of species is not closely related the other Nardia species, although some small depauperate phases of $N$. unispiralis are hardly differentiable from $N$. breidleri (Limpr.) Lindb. - the circumboreal ecological vicariant of the former, occurring in the similar niches.

The description of $N$. hiroshii was published only once and was based on two specimens from Honshu (Amakawa, 1959); it therefore seems reasonable to present the description based on the North American specimen with addition of some new information on ecology of the taxon.

Nardia hiroshii Amakawa, J. Hattori Bot. Lab. 21: 283. 1959.

Fig. 1.

Plants ascending to (rarely) creeping, whitish to pale green and yellowish, commonly with apical portions of the leaves brownish golden, 1.1-1.4 mm wide (perianthous up to $2 \mathrm{~mm}$ ), ca. 5-10 mm long. Stem 0.18-0.30 mm in diameter, loosely transversely elliptic in cross section, sparsely laterally branched; cortex obscurely developed, cells in outer layer nearly rounded, ca. 19-25 $\mu \mathrm{m}$ in diameter, to the middle irregular in shape, mostly 6-7-gonal, ca. $28-44 \mu \mathrm{m}$ in diameter, thin- to slightly thick-walled (slightly thicker in outer layer), with concave trigones medium in size. Rhizoids sparse to dense, mostly in indistinct fascicles, more rarely not clustered, erect spreading from the stem, originated near ventral leaf bases and bases of underleaves, colorless to brownish. Leaves contiguous to distant, subtransversely to subobliquely inserted (at ca. $30-45^{\circ}$ with stem axis), with barely or shortly decurrent dorsal leaf base; divided by obtuse-angular to loosely gibbous sinus descending for $1 / 5-1 / 4$ of leaf length into two triangular obtusely apiculate lobes, mostly deeper brownish golden colored near lobe apices; moderately concave to concave-canaliculate, transversely elliptic to trapezoidal, $0.65-0.75 \times 0.75-0.85(0.9) \mathrm{mm}$ (length to width ratio is $1: 0.85-0.95)$. Underleaves laciniate to narrowly triangular, rarely with additional unicellular tooth near base, sometimes connate with ventral base of one leaf of each pair; rarely underleaves hidden in the rhizoids and then invisible, 3-6 cells wide at the base and 5-8(10) cells long (ca. 200-280×60-140 $\mu \mathrm{m}$ ). Midleaf cells mostly 5-6-gonal, 28-53 $\times 25-42 \mu \mathrm{m}$, thin-walled, trigones moderate in size, triangular to convex, walls colorless to pale yellowish; near lobe apex walls brownish, trigones triangular to convex, lumen rounded, ca. 28-34 $\mu \mathrm{m}$ in diameter; near the base $30-47 \times 25-41 \mu \mathrm{m}$, thin-walled, trigones convex, walls colorless. Oil-bodies in the midleaf cells 2-5 per cell, $11-20 \times 8 \mu \mathrm{m}$, irregularly elliptic, finely granulate (were present in the material 10 years old). Perianth terminal, conical, loosely plicate, ca. $0.5 \times 0.8 \mathrm{~mm}$, with loosely beaked mouth, hidden within bracts. Perigynium with 3 
pairs of leaves, turned up by ca. $20^{\circ}$ from stem axis, strongly rhizogenous, ca. $1.5 \mathrm{~mm}$ long. Bracts similar to leaves, but more deeply lobate and having obviously apiculate lobes, undulate and crispate at margin. Bracteoles become bigger to the pair adjacent to the perianth, vary from 0.4 $\mathrm{mm}$ long in third pair (downward from the perianth) to $0.8 \mathrm{~mm}$ long in upper pair, triangular to narrowly triangular, the biggest bracteole undulate at margin. [Spores 13-15 $\mu \mathrm{m}$ in the diameter, finely papillose, deep brown, elaters bispiral, 7-8 $\mu \mathrm{m}$ thick (based on the specimen from the South Kurils, Bakalin et al., 2009).]

Specimen examined: U.S.A., California, Nevada County. $120^{\circ} 20^{\prime} \mathrm{W}, 39^{\circ} 21^{\prime} \mathrm{N}$, elev. $7200 \mathrm{ft}$. (2194 m), leg. A.T. Whittemore 415718 Oct. 1992 (MO3966877).

The ecology of the taxon is poorly known. Most probably it is confined to fine-grained soil with disturbed or undeveloped vegetation cover. In California, the specimen was collected on "soil at edge of meadow with Salix along stream channels, in open Pinus contorta Douglas ex Loudon - P. monticola Douglas ex D. Don - Abies forest; bedrock granite". The plants form loose pure mat. In the South Kurils, Nardia hiroshii grows on stones covered by soil, in crevices on tufa composed cliffs along streams, crater's lake banks, on bare soil near glaciers and in tectonic breakings. Here $N$. hiroshii forms pure mats or usually is associated with Anthelia juratzkana (Limpr.) Trevis., Blepharostoma trichophyllum (L.) Dumort., Cephalozia bicuspidata (L.) Dumort., Conocephalum japonicum (Thunb.) Grolle, Diplophyllum taxifolium (Wahlenb.) Dumort. and Lophozia savicziae Schljakov. In Japan, this species grows "on humus on rocks in the alpine region" (Amakawa, 1959: 285). In Honshu, it is recorded up to $2400 \mathrm{~m}$ elev., in the colder Kurils it occurs from 60 to $1460 \mathrm{~m}$ elev. Nardia hiroshii prefers in general subalpine and alpine vegetation types, as well as lowered variants of tundroid communities (as a result of thermal inversion and severe wind regime). The American locality lies within a similar altitudinal range. Apparently, the species will be found in other localities in western North America after a future researches.

Since Nardia occuring around North Pacific has never undergone any special treatment and no identification keys exist it would be reasonable to provide here the key to Nardia of this area. The key was prepared based on the review of western North American Nardia (Hong \& Váňa, 2000), distribution maps of Russian Far East hepatics (Bakalin, 2010), the list of Korean bryophytes (Park \& Choi, 2007), the small addition to Korean hepatics flora (Choi et al., 2011), the revision of Nardia in Japan (Amakawa, 1959), the catalogue of Japanese hepatics (Yamada \& Iwatsuki, 2006), as well as my own materials collected in the Russian Far East. Additionally I used very helpful treatment of Nardia published by Váňa (1976), and, as minor addition, the revision of Nardia sect. Subclavatae in Russia by Bakalin (2008). The key covers the area of the western U.S.A. (Alaska, Washing- ton, Oregon, and California), Canada (British Columbia), Russian Far East (Chukotka, Magadan, Sakhalin Provinces and Kamchatka, Khabarovsk and Primorsky Territories), the Korean Peninsula, and Japan. Regions from which the species were recorded within the treated area are indicated in square brackets.

\section{KEY TO NARDIA IN NORTH PACIFIC}

1. Leaves laterally appressed to stem, beyond the stem both in ventral and dorsal sides, more or less plane; oil-bodies 2-3 per midleaf cell, homogenous to loosely botryoidal; underleaves vestigial; stem hyalodermis present [Alaska, British Columbia, Washington; Japan; Kamchatka, Sakhalin] N. compressa (Hook.) Gray

- Leaves not appressed laterally to stem, beyond the stem dorsally only, concave to concave-canaliculate, sometimes undulate at margin; oil-bodies 1-6 per cell, homogenous, botryoidal to granulate; underleaves vestigial or virtually absent to large; stem hyalodermis absent ....................................................... 2

2. Leaves entire to retuse; perigynium axis is the same with stem axis (not incurved as compared with stem), perianth well-developed, usually exerted; oil-bodies by one in $20-90 \%$ of leaf cells; underleaves large; rhizoids originated mostly near underleaf bases (sect. Subclavatae H. Inoue) .

- Leaves entire to deeply bilobed; perigynium incurved (at ca $20-90^{\circ}$ with stem axis); perianth generally reduced, entirely hidden within bracts; oil-bodies present in all leaf cells, 2-6 per cell (rarely one per cell in minute $N$. breidleri); rhizoids distributed continuously along the stem or concentrated near underleaf bases

3. Shoots $0.8-1.3 \mathrm{~mm}$ wide; underleaves usually connate with one leaf (rarely with both leaves) of pair; trigones in leaf cells medium in size, convex to nodulose; oil-bodies present in 70-90\% of leaf cells [Japan; Korea; Sakhalin] N. subclavata (Steph.) Amakawa

- Shoots 0.4-1.0 mm wide; underleaves usually not connate with leaves; trigones small, concave; oilbodies present in 20-50(-70)\% of leaf cells [Japan; Korea; Kamchatka, Khabarovsk, Primorsky, Sakhalin] .......................... N. assamica (Mitt.) Amakawa

4. Plants of "lophozioid" appearance; leaves bilobed, with acute lobes, sometimes undulate at margin and sheathing in the base; oil-bodies granulate, 2-5 per midleaf cell; underleaves laciniate to disappearing; elaters with 1-2 spirals

- Plants of "nardioid" appearance; leaves unlobed to bilobed, with obtuse lobes, margin plane, base not sheathing; oil-bodies 1-6 per mildleaf cell, granulate to homogenous; underleaves spatulate to laciniate, filiform and disappearing; elaters with 2-4 spirals 
5. Elaters bispiral; underleaves always regular, although sometimes small and hardly visible due to the rhizoids cover, up $280 \mu \mathrm{m}$ long; rhizoids originated mostly near the underleaf bases [California; Japan; Sakhalin] N. hiroshi Amakawa

- Elaters unispiral; underleaves regular to usually disappearing, up to $160 \mu \mathrm{m}$ long; rhizoids distributed throughout along ventral side of stem [Japan; Kamchatka, Sakhalin] .............. N. unispiralis Amakawa

6. Plants filiform, up to $0.5 \mathrm{~mm}$ wide, with distant, sometimes scale-like leaves, rarely with contiguous to imbricate leaves; oil-bodies one per midleaf cell, granulate; underleaves filiform, easily deciduous and usually disappearing [Alaska, British Columbia, Washington; Japan; Kamchatka, Sakhalin] N. breidleri (Limpr.) Lindb.

- Plants not filiform, more than $0.5 \mathrm{~mm}$ wide, leaves contiguous to imbricate; oil-bodies 2-6 per cell; underleaves regular, spatulate to laciniate and filiform

7. Underleaves spatulate to rarely lanceolate; rhizoids usually originated near underleaf and ventral leaf bases; oil-bodies homogenous to botryoidal .......... 8

- Underleaves laciniate to filiform, rarely lanceolate (in larger perianthous shoots); rhizoids distributed continuously along ventral side of the stem; oil-bodies homogenous to granulate 9

8. Leaves unlobed to retuse; oil-bodies botryoidal [Japan; Sakhalin]

... N. scalaris Gray ssp. harae (Amakawa) Amakawa

- Leaves bilobed by obtuse to triangle and gibbous sinus; oil-bodies homogenous [Alaska, British Columbia, Oregon, Washington; Japan; Chukotka, Kamchatka, Khabarovsk, Sakhalin]

$N$. japonica Steph.

9. Leaves unlobed; underleaves erect spreading, laciniate to filiform, regular, easily visible; oil-bodies homogenous [Alaska, British Columbia, California, Oregon, Washington; Chukotka, Kamchatka, Magadan, Sakhalin] ............... N. scalaris S.Gray ssp. scalaris

- Leaves unlobed to bilobed; underleaves filiform, appressed to the stem, regular, but usually hardly visible; oil-bodies homogenous to granulate ............ 10

10. Midleaf cells $30-40 \mu \mathrm{m}$ wide, trigones medium to large, convex; oil-bodies 2-5 per cell, granulate; paroicous [Alaska, Washington; Chukotka, Kamchatka, Sakhalin]..... Nardia insecta Lindb.

- Midleaf cells 20-30 $\mu \mathrm{m}$ wide, trigones usually concave, rarely convex (but then oil-bodies homogenous); oil-bodies granulate to homogenous; paroicous to dioicous .
11. Oil-bodies homogenous, 2-3(-4) per cell, trigones usually moderate in size, convex; leaves bilobate at least up to $1 / 3$ of leaf length; dioicous . $N$. japonica Steph. p.p. (a phase rare in our area, but rather common in northern Europe and Siberia; see couplet 8)

- Oil-bodies granulate, 2-6 per cell, trigones small, concave; leaves mostly unlobed to retuse, rarely divided by sinus descending up to $1 / 4$ of leaf length . ..... 12 (Nardia geoscyphus (De Not.) Lindb. s.1. )

12. Plants dioicous; leaves unlobed to retuse at apex [Sakhalin].....

$N$. geoscyphus (De Not.) Lindb. var. dioica Bakalin

- Plants paroicous; leaves unlobed to retuse and lobed by sinus descending up to 1/4 of leaf length [Alaska, British Columbia, California, Oregon, Washington; Chukotka, Kamchatka, Khabarovsk, Magadan, Sakhalin]....

... N. geoscyphus (De Not.) Lindb. var. geoscyphus ACKNOWLEDGEMENTS

The figure was kindly prepared by Mr. M.A. Bakalin to whom I am sincerely grateful. I am also deeply indebted to Dr. Richard Zander (MO) and to Flora of North America association for the financial support of the visit to Missouri Botanical Garden (MO). I am very grateful for the review and helpful comments to Dr. N.A. Konstantinova. The laboratory work was partially supported by RFBR (10-04-00050, 12-04-91150-ГФЕН).

\section{LITERATURE CITED}

AMAKAWA, T. 1959. Family Jungermanniaceae of Japan. I. - J. Hattori Bot. Lab. 21: 244-291.

[BАКАLIN, V.А.] БАКАЛИН В.А. 2008. Nardia sect. Subclavatae (Jungermanniaceae, Hepaticae) в России. - [The species of Nardia sect. Subclavatae (Jungermanniaceae, Hepaticae) in Russia] Бom. журн. [Bot. Zhurn.] 93(11): 1794-1800.

BAKALIN, V.A. 2010. The distribution of bryophytes in the Russian Far East. Part. I. Hepatics. Vladivostok, Publishing company of Far-Eastern University, $175 \mathrm{pp}$.

BAKALIN, V.A., V.YA. CHERDANTSEVA, M.S. IGNATOV, E.A. IGNATOVA \& T.I. NYUSHKO 2009. Bryophyte flora of the South Kuril Islands (East Asia). - Arctoa 18: 69-114.

CHOI, S.S., V.A. BAKALIN, C.H. KIM \& B.Y. SUN 2011. Unrecorded liverwort species from Korean flora: Alobiellopsis parvifolius (Cephaloziaceae), Calypogeia japonica (Calypogeiaceae), Hattoria yakushimensis (Lophoziaceae), Nardia subclavata (Solenostomataceae). Korean J. Plant Taxonomy. 41(3): 230-234.

HONG, W.S. \& J. VÁŇA 2000. The distribution of Nardia in western North America. - Lindbergia 25: 9-14.

PARK, K.W. \& K. CHOI 2007. New list of Bryophytes in Korea. - Korean National Arboretum, Pocheon, $150 \mathrm{pp}$.

VÁŇA, J. 1976. Studies über die Jungermannioideae (Hepaticae) 10. Nardia. - Folia Geobot. et Phytotax. 11: 367-425.

YAMADA, K. \& Z. IWATSUKI 2006. Catalog of the hepatics of Japan.J. Hattori Bot. Lab. 99: 1-106. 